\title{
A STATISTICAL STUDY ON CROPPING PATTERN CHANGES IN MADURAI DISTRICT
}

\author{
K.Arulpandiyan ${ }^{1}$ and K. Prabakaran ${ }^{2}$ \\ ${ }^{1}$ PG Scholar in Agricultural Statistics, Tamil Nadu Agricultural University, Coimbatore, Tamil Nadu, India. \\ ${ }^{2}$ Assistant Professor (Agricultural Statistics), Department of Agricultural Economics, Agricultural College \& \\ Research Institute, Madurai, Tamil Nadu, India.
}

DOI: 10.46609/IJAER.2020.v06i03.015 URL: https://doi.org/10.46609/IJAER.2020.v06i03.015

\begin{abstract}
The study was carried out Madurai district major rainfed crops cultivating taluk of Thirumangalam and Sedapatti taluks. In Thirumangalam and Sedapatti taluk changes in cropping pattern was studied by using Markov chain analysis and the results showed that the rainfed area under green gram was most stable crop and other rainfed crops area was considered in the study have less stability. The result revealed that the retained area was almost similar ranging from $35 \%$ to $45 \%$ in all rainfed crops in Thirumangalam taluk. In Sedapatti taluk the results showed that the rainfed area under cotton was most stable crop and other rainfed crops area was considered in the study have less stability.
\end{abstract}

Keywords: Cropping pattern, Markov chain analysis, Rainfed crops.

\section{INTRODUCTION}

A change in cropping pattern implies a change in proportion of area under different rainfed crops. It has significant bearing on widening the geographical inequalities in income distribution. A dynamic change has been witnessed in agricultural scene in our country, particularly during post-green revolution period. Cropping pattern refers to adoption of particular type of rainfed crops by the farmers in a particular region. It is expressed at macro level, that is, district, taluk or village level. Hence, present study was conducted with the specific objective to analyze the structural changes in cropping pattern over the years in Thirumangalam and Sedapatti taluk of Madurai district. 


\section{MATERIALS AND METHODS}

For the purpose of analyzing the changes in cropping pattern, Thirumangalam and Sedapatti taluk of Madurai district was purposively selected. The major area under cultivation based rainfed crops such as sorghum from cereals, red gram and green gram from pulses, groundnut from oil seeds and cotton from commercial crops were purposively selected for this study. The time series data were obtained for a period of 15 years (2003-04 to 2017-18).The data were collected from various issues of "Regional statistical office of economics and statistics" from 2003-04 to 2017-18.

\section{Markov chain analysis}

The Markov chain analysis is an application of dynamic programming to the solution of a stochastic decision process that can be described by a finite number of states. The Markov process was used to study the shifts in the shares of crops which facilitated the understanding of the dynamics of crop changes.

\section{The Markov probability model}

A stochastic process is one analyze a set of trials or experiments probabilistically. For stochastic process if $\mathrm{N}$ assumed that the movements (transitions) of objects from one division (possible outcome) to another are governed by a probability mechanism or system. A finite Markov process is a stochastic process whereby the outcome of a given trial $t(1=1,2, . . \mathrm{T})$ depends only on the outcome of the preceding trial (t-1) and this dependence is the same at all stage in the sequence of trials. Consistence with this definition,

Let $\mathrm{S}$; represent the $\mathrm{r}$ tehsil or possible outcomes; $\mathrm{i}=1,2 \ldots . \mathrm{r}$.

$\mathrm{W}_{\mathrm{it}}$ represents the probability that tehsil $\mathrm{S}_{\mathrm{i}}$ occurs on trial $\mathrm{t}$ or the proportion observed in trial $\mathrm{t}$ in alternative outcome tehsil i.e. of a multinomial population based on a sample of size n, i.e. $\operatorname{Pr}$ $\left(\mathrm{S}_{\mathrm{it}}\right) . \mathrm{P}_{\mathrm{it}}$ represent the transitional probability that which denotes the probability that if for any time $t$ the process is in state $S_{i}$ it moves on the next trial to division $S_{j}$ i.e. Pro $\left(S_{j t}+1 / S_{j t}\right)=P_{i j}$. $\mathrm{P}=\left(\mathrm{P}_{\mathrm{ij}}\right)$ represent the transitional probability matrix which denotes the transitional probability for every pair of tehsil $(i, j=1,2 \ldots . r)$ and has the following properties.

$0<\mathrm{P}_{\mathrm{ij}}<1$ (1) and

$\sum P=1$, for $\mathrm{i}=1,2$ 
Given this set of notations and definitions for a first order Markov chain the probability of a particular sequence $S_{i}$ on trial $t$ and $S_{t}$ on trial $t+1$ may be represented by

$\operatorname{Pr}\left(S_{j t} S_{j t}+1\right)=\operatorname{Pr}\left(S_{j t}\right) \operatorname{Pr}\left(S_{j t}+1 / S_{j t}\right)=W_{i t} P_{j t}$ ..(3) and

the probability of being in division $\mathrm{j}$ at trial $\mathrm{t}+1$ may be represented by

$\operatorname{Pr}\left(\mathrm{S}_{\mathrm{j}} \mathrm{t}+1\right)=\sum W_{i t} P_{i t}$ or $\mathrm{i}$

$\mathrm{W}_{\mathrm{t}} \mathrm{t}+1=\sum W_{i t} P_{t j}$

The data for the study are the proportion of area under selected crops. These proportions change from year to year as result of the factors like weather, technology, price and other institutional change. It is reasonable to assume that the combined influence of these individually systematic forces approximate to a stochastic proceeds and the propensity of farmers to move from one crop to another differs according to the crop involved in tehsil. If these assumptions are acceptable, then the process of cropping pattern change may be described in the form of a matrix $p$ of first order transitional probabilities. The element of $\mathrm{P}_{\mathrm{ij}}$ of the matrix indicates the probability of a farmer in crop division in one period will more to crop division $\mathrm{j}$ during the following period. The diagonal element $P_{i j}$ measures the probability that the proportion share of $j^{\text {th }}$ category of crop were maintained.

\section{Estimation of Transition Probability Matrix:}

Equation (4) as a basis for specifying the statistical model for estimating the transition probabilities. If errors are incorporated in equation (4) to account for the difference between the actual and estimated occurance of $\left(\mathrm{W}_{\mathrm{j}} \mathrm{t}+\mathrm{l}\right)$, the sample observations assumed to be generated by the following Linear Statistical Model.

$\mathrm{W}_{\mathrm{jt}}=\sum W_{t} \mathrm{t}-1 \mathrm{P}_{\mathrm{ij}}+\mathrm{U}_{\mathrm{jt}}$

Or in Matrix form it can be written as

$\mathrm{Y}_{\mathrm{j}}=\mathrm{X}_{\mathrm{j}} \mathrm{P}_{\mathrm{j}}+\mathrm{U}_{\mathrm{j}}$

Where,

$Y_{j}$ is a ( $\left.\mathrm{T} \times 1\right)$ vectors of observations reflecting the proportion in cropping pattern $\mathrm{j}$ in time $t, \mathrm{x}_{\mathrm{j}}$ is a ( $\mathrm{T} \times \mathrm{R}$ ) matrix of realized values of the proportion in cropping pattern $\mathrm{i}$ in time $\mathrm{t}-1, \mathrm{P}_{\mathrm{j}}$ is a (rx1) vector of unknown transition parameters to be estimated and $\mathrm{U}_{\mathrm{j}}$ is a vector of random disturbances. 
International Journal of Agriculture and Environmental Research

ISSN: 2455-6939

Volume: 06, Issue: 03 "May-June 2020"

\section{RESULT AND DISCUSSION}

The results of the transition probability matrix for rainfed crops in Thirumangalam and Sedapatti taluk of Madurai district are given Table 1 and Table 2.

Table 1 revealed that sorghum crop had retained $35.91 \%$ of the previous years share of area and lost about $63.99 \%$ of its previous years share to green gram. However, its gained about $15.94 \%$ area from green gram and $36.48 \%$ from cotton crop. Red gram retained $43.21 \%$ of the previous years share of area and lost about $40.12 \%$ of its previous years share to groundnut and $16.65 \%$ to cotton. However, its gained about $2.54 \%$ area from groundnut. Green gram retained $45.23 \%$ of the previous years share of area and lost about $38.85 \%$ to cotton and $15.94 \%$ to sorghum crop. However, its gained about $63.99 \%$ from sorghum and $21.56 \%$ from cotton crop. Groundnut retained $41.23 \%$ of previous years share of area and lost about $56.22 \%$ to cotton and $2.54 \%$ to red gram. However, it's gained about $40.12 \%$ from red gram. Cotton retained $41.94 \%$ of the previous years share of area and lost about $36.48 \%$ of its previous years share to sorghum crop and $21.56 \%$ to green gram. However, its gained about $56.22 \%$ from groundnut, $38.85 \%$ from green gram and $16.65 \%$ from red gram. The result revealed that the retained of area was almost similar ranging from $35 \%$ to $45 \%$ in all rainfed crops in Thirumangalam taluk.

Similar results was obtained by lamani (2003) and recorded that transitional probability matrix for taluka wise for cropping pattern changes of rainfed crops in Dharwad district. She also obtained result of the retained area was almost similar ranging from $38 \%$ to $44 \%$ in all rainfed crops in Dharwad taluk of Dharwad district.

Table 2 revealed that the highest retention of area was noticed in Cotton crop (62.13\%) followed by groundnut (57.23\%), Green gram (52.98\%), Sorghum (36.88\%) and Red gram (31.21\%). Sorghum crop retained $36.88 \%$ of the previous years share of area and lost about $63.12 \%$ of its previous years share to green gram. However, it gained about $7.15 \%$ area from green gram. Red gram retained $31.21 \%$ of the previous years share of area and lost about $41.12 \%$ of its previous years share to groundnut and $27.57 \%$ to cotton. However, its gained about $41.49 \%$ area from groundnut, $11.42 \%$ from green gram and $7.52 \%$ from cotton. Green gram retention $52.98 \%$ of the previous years share of area and lost about $28.45 \%$ to cotton, $11.42 \%$ to red gram and $7.15 \%$ to sorghum crop. However, its gained about $63.12 \%$ from sorghum and $18.84 \%$ from cotton crop. Groundnut retained $57.23 \%$ of previous years share of area and lost about $1.24 \%$ to cotton and $41.49 \%$ to red gram. However, it's gained about $41.21 \%$ to red gram and $11.44 \%$ from cotton. Cotton retained $62.13 \%$ of the previous years share of area and lost about $18.84 \%$ to green gram crop and $7.52 \%$ to red gram. However, its gained about $1.24 \%$ from groundnut, $28.45 \%$ from green gram and $27.57 \%$ from red gram. The result showed that highest retained of area was noticed green gram, groundnut and cotton crop ranging from $52 \%$ to $62 \%$ and other two 
crop ranging less from $31 \%$ to $37 \%$. This was probably because the cultivation of green gram, groundnut and cotton was more remunerative when compared to sorghum and red gram.

Similar results was obtained by kumar and basvaraja (2012) and studied that for structural changes in cropping pattern in northern transitional zone of Karnataka. He obtained cropping pattern changes was probably because the cultivation of paddy, wheat, jowar, groundnut and chickpea was less remunerative when compared to maize and cotton crop.

Table 1: Transitional probability matrix for cropping pattern change in Thirumangalam taluk

\begin{tabular}{|c|c|c|c|c|c|}
\hline \multicolumn{7}{|c|}{ Thirumangalam taluk } \\
\hline Crops & Sorghum & Red gram & Green gram & Groundnut & Cotton \\
\hline Sorghum & $\mathbf{0 . 3 5 9 1}$ & 0.0000 & 0.6399 & 0.0000 & 0.0000 \\
\hline Red gram & 0.0000 & $\mathbf{0 . 4 3 2 1}$ & 0.0000 & 0.4012 & 0.1665 \\
\hline Green gram & 0.1594 & 0.0000 & $\mathbf{0 . 4 5 2 3}$ & 0.0000 & 0.3885 \\
\hline Groundnut & 0.0000 & 0.0254 & 0.0000 & $\mathbf{0 . 4 1 2 3}$ & 0.5622 \\
\hline Cotton & 0.3648 & 0.0000 & 0.2156 & 0.0000 & $\mathbf{0 . 4 1 9 4}$ \\
\hline
\end{tabular}

Table 2: Transitional probability matrix for cropping pattern change in Sedapatti taluk

\begin{tabular}{|c|c|c|c|c|c|}
\hline \multicolumn{7}{|c|}{ Sedapatti taluk } \\
\hline Crops & Sorghum & Red gram & Green gram & Groundnut & Cotton \\
\hline Sorghum & $\mathbf{0 . 3 6 8 8}$ & 0.0000 & 0.6312 & 0.0000 & 0.0000 \\
\hline Red gram & 0.0000 & $\mathbf{0 . 3 1 2 1}$ & 0.0000 & 0.4121 & 0.2757 \\
\hline Green gram & 0.0715 & 0.1142 & $\mathbf{0 . 5 2 9 8}$ & 0.0000 & 0.2845 \\
\hline Groundnut & 0.0000 & 0.4149 & 0.0000 & $\mathbf{0 . 5 7 2 3}$ & 0.0124 \\
\hline Cotton & 0.0000 & 0.0752 & 0.1884 & 0.1144 & $\mathbf{0 . 6 2 1 3}$ \\
\hline
\end{tabular}




\section{LITERATURE CITED}

1. Goswami, S.N., Dubey, P.N. and Challa, O. (2003). Land use dynamics in Mizoram, Agric. Situ. India, 60(8) : $531-538$.

2. Rao Dayakar and Shahid Parwez (2005). Dynamics of cropping pattern in sorghum growing states of India. Indian J. Agric. Econ., 60(4) : $644-659$.

3. Singh and Kaur, P. (1991). Structural changes in Punjab agriculture. Agric. Situ. India, $25(2): 330-335$.

4. Aravind, K., \& Basvaraja, H. (2012). Structural changes in cropping pattern in Northern transitional zone of Karnataka. International Research Journal of Agricultural Economics and Statistics, 3(2), 197-201.

5. Suresh banu lamani (2003). "Multivariate analysis to study the impact of weather parameters on production of rainfed crops of dharwad district" 